\title{
Dehardening Kinetics, Bud Development, and Dehydrin Metabolism in Blueberry Cultivars during Deacclimation at Constant, Warm Temperatures
}

\author{
Rajeev Arora ${ }^{1}$ \\ Iowa State University, Department of Horticulture, 139 Horticulture Hall, Ames, IA 50011-1100
}

\author{
Lisa J. Rowland, Elizabeth L. Ogden, and Anik L. Dhanaraj \\ U.S. Department of Agriculture, Agricultural Research Service, Henry A. Wallace Beltsville Agricultural \\ Research Center, Fruit Laboratory, Building 010A, BARC-West, Beltsville, MD 20705
}

Calin O. Marian

Department of Biological Sciences, Florida State University, Tallahassee, FL 32306

Mark K. Ehlenfeldt

U.S. Department of Agriculture, Agricultural Research Service, Philip E. Marucci Center for Blueberry and Cranberry Research and Extension, 125A Lake Oswego Road, Chatsworth, NJ 08019

\begin{abstract}
Bryan Vinyard
U.S. Department of Agriculture, Agricultural Research Service, Henry A. Wallace Beltsville Agricultural Research Center, Biometrical Consulting Service, Building 005, BARC-West, Beltsville, MD 20705
\end{abstract}

\begin{abstract}
ADDITIONAL INDEX wORDS. cold hardiness, freezing tolerance, Vaccinium
Aвstract. Loss of freeze tolerance, or deacclimation, is an integral part of winter survival in woody perennials because untimely mid-winter or spring thaws followed by a hard freeze can cause severe injury to dehardened tissues. This study was undertaken to investigate deacclimation kinetics, particularly the timing and speed, of five blueberry (Vaccinium L.) cultivars ('Bluecrop', 'Weymouth', 'Ozarkblue', 'Tifblue', and 'Legacy'), with different germplasm compositions and mid-winter bud hardiness levels, in response to an environmentally controlled temperature regime. Based upon bud cold hardiness evaluations in $\mathbf{2 0 0 0}$ and 2001, 'Tifblue', a Vaccinium ashei Reade cultivar, was one of the least hardy and the fastest to deacclimate; 'Bluecrop', a predominantly $V$. corymbosum $L$. cultivar, was the most hardy and the slowest to deacclimate; and 'Ozarkblue', a predominantly $V$. corymbosum cultivar but including southern species $V$. darrowi Camp. and $V$. ashei, was intermediate in speed of deacclimation. 'Weymouth' (predominantly V. corymbosum) and 'Legacy' $(73.4 \% \mathrm{~V}$. corymbosum and $25 \% \mathrm{~V}$. darrowi) were slow to intermediate deacclimators. Deacclimation rates did not correlate strictly with mid-winter bud hardiness. Data suggest that the southern germplasm component $V$. ashei may be responsible for the observed faster deacclimation whereas both southern species, $V$. darrowi and $V$. ashei, may contribute genes for cold sensitivity. Strong positive correlations between stage of bud opening and bud cold hardiness existed in both years $(r=0.90$ and 0.82 in 2000 and 2001 study, respectively). Previously identified major blueberry dehydrins, 65-, 60-, and 14-kDa, progressively decreased in their abundance during incremental dehardening in 'Bluecrop', 'Weymouth', and 'Tifblue'. However, down-regulation of the 14-kDa dehydrin most closely mirrored the loss in cold hardiness during deacclimation, and, therefore, may be involved in regulation of bud dehardening. Because differences in deacclimation rate were clearly evident among the genotypes studied, rate of deacclimation of the flower buds of blueberry should be an important consideration in breeding to improve winter survival.
\end{abstract}

The United States is the world's leading blueberry producer. The blueberry industry in the United States, however, suffers from a lack of cold-hardy cultivars (Moore, 1993). Cold (freeze-) injury in various tissues can occur due to freezing conditions prior to hardening (cold acclimation), low mid-winter temperatures that exceed the limits of the plant's tolerance, or hard freezes after deacclimation (loss in freeze-tolerance due to unseasonably warm

Received for publication 22 Oct. 2003. Accepted for publication 2 Mar. 2004 Contribution of the Iowa Agriculture and Home Economics Experiment Station, Ames, Iowa, Project No. 3601, and supported by Hatch Act and State of Iowa funds.

1To whom reprint requests should be addressed; e-mail: rarora@iastate.edu; tel: 515-294-0031; fax: 515-294-0730, spells during winter/early spring). Often a new cultivar that otherwise may appear very promising for a particular growing area in test-plot evaluations may not get unequivocal endorsement by the industry due to lack of information regarding its cold hardiness. This is particularly true for blueberry selections that have some component of southern germplasm in their backgrounds. Ideally, blueberry cultivars for the United States should acclimate to cold quickly in the fall, have a high mid-winter hardiness (actual level dependent on where the cultivar is to be grown), and deacclimate slowly during spring or during unseasonably warm spells in winter without adversely delaying time of fruiting.

Over the past several years, our research has focused on studying the genetics and physiology of cold acclimation and mid-winter hardiness of blueberry toward an ultimate goal of applying the 
information learned in developing more cold-hardy cultivars. For example, these studies have demonstrated that accumulation kinetics and levels of certain dehydrin proteins (and their gene transcripts) are correlated with seasonal development and levels of cold hardiness (Arora et al., 1997; Levi et al., 1999; Muthalif and Rowland, 1994). We have also made progress toward mapping quantitative trait loci (QTLs) controlling mid-winter cold hardiness (Rowland et al., 1999, 1993). However, until now, no systematic approach has been undertaken to study the deacclimation process in blueberry, even though it is an integral part of winter survival and reproductive success, as untimely winter or early spring thaws followed by hard freezes can cause severe injury to dehardened flower buds.

There are many questions that need to be explored concerning the deacclimation process in blueberry. For example, at present no information exists on the temperature or the length of time at a given temperature required to trigger deacclimation. What is the kinetics (timing and speed) of deacclimation in blueberry, and does it vary among genotypes? Is the rate or extent of deacclimation under a given temperature regime correlated with mid-winter cold hardiness? Does the extent of bud opening in response to warmer temperatures correlate with the level of dehardening? What is the fate of accumulated dehydrins during dehardening, and does their metabolism correlate with changes in freezing tolerance? This study was undertaken to investigate deacclimation kinetics, particularly the timing and the rate, in response to an environmentally controlled temperature regime in five cultivars of blueberry with different germplasm compositions and mid-winter cold hardiness levels. Experiments were also conducted to examine the relationship between bud opening during the dehardening regime and the level of bud hardiness. Additionally, levels of three dehydrins of 65-, 60-, and 14-kDa, previously implicated in induction of cold acclimation in blueberry (Arora et al., 1997; Levi et al., 1999; Muthalif and Rowland, 1994), were monitored during deacclimation.

\section{Materials and Methods}

Plant material. Five blueberry cultivars were used for this study: 'Bluecrop', 'Weymouth', 'Legacy', 'Ozarkblue', and 'Tifblue'. Based on either their known mid-winter bud hardiness (in the case of 'Bluecrop' and 'Tifblue') from our previous studies (Arora et al., 1997; Muthalif and Rowland, 1994) or their germplasm composition (relative amount of northern highbush and southern germplasm in their ancestry) (Clark et al., 1996; Ehlenfeldt, 1994; Hancock and Sieker, 1982), these cultivars were expected to represent a range of bud-hardiness levels, and, therefore, were selected for this study. 'Bluecrop' and 'Weymouth', the northern highbush cultivars, are composed predominantly of $V$. corymbosum, with small percentages of $V$. angustifolium Ait. and no southern germplasm, whereas 'Legacy', 'Ozarkblue', and 'Tifblue' have various amounts of southern germplasm from either $V$. ashei or V. darrowi in their ancestry (Table 1). Experimental material came from mature 'Tifblue' plants grown in field plots at the Henry A. Wallace Agricultural Research Station at Beltsville, Md., and, for the other four cultivars, from mature plants on a commercial farm in Hammonton, N.J.

DeacClimation Regime. Approximately 130-150 shoots with six to 10 attached floral buds were excised in mid-February of 2000 and 2001 representing a random pool of fully cold-acclimated buds. Deacclimation regime included placing cold-acclimated shoots in Erlenmeyer flasks with the base of the shoots submerged in distilled-deionized water and exposing them to constant temperature $\left(20^{\circ} \mathrm{C}\right)$ and photosynthetically active radiation $(P A R)$ $\left(100 \mu \mathrm{E} \cdot \mathrm{cm}^{-2} \cdot \mathrm{s}^{-1}\right)$. For the 2000 study, buds of three cultivars ('Bluecrop', 'Weymouth', and 'Tifblue') were deacclimated under these environmental conditions for increasing $\approx 3$ - $d$ intervals up to 16 d. During the 2001 deacclimation study, buds from five blueberry cultivars (three as in the 2000 study plus 'Legacy' and 'Ozarkblue') were deacclimated for increasing 1-d intervals up to $6 \mathrm{~d}$. Every other day, the bases of the shoots were submerged in fresh water and recut to prevent fungal growth. The appropriate number of shoots (see below) was sampled periodically through the decclimation time-course beginning with Day 0 (fully cold acclimated buds) and subjected to a controlled freeze-thaw regime for evaluating bud hardiness.

DETERMINATION OF BUD COLD HARDINESS (BCH). Five- to sixcentimeter-long shoots with three to eight buds attached were subjected to a freeze-thaw protocol as described by Arora et al. (2000). The freeze-thaw test consisted of placing three randomly sampled shoots/treatment temperature/deacclimation sampling from each cultivar in test tubes (one shoot/tube) with $0.5 \mathrm{~mL}$ of water and subjecting them to controlled freezing in a glycol bath (model 2325; Forma Scientific, Marietta, Ohio). Ice nucleation was initiated at $-1{ }^{\circ} \mathrm{C}$, samples were allowed to equilibrate for 2 $\mathrm{h}$, and further cooled at $0.5^{\circ} \mathrm{C} / 30 \mathrm{~min}$ down to $-4{ }^{\circ} \mathrm{C}, 1{ }^{\circ} \mathrm{C} / 30 \mathrm{~min}$ down to $-8^{\circ} \mathrm{C}$, and $2{ }^{\circ} \mathrm{C} / 30 \mathrm{~min}$ thereafter to respective treatment temperatures. Bud temperature was monitored by copper-constantan thermocouples (TT-T-30) attached to a thermometer (DP465; Omega Engineering, Stamford, Conn.). Treatment temperatures chosen for fully cold-acclimated buds ranged from -8 to $-31^{\circ} \mathrm{C}$ in 2 to $3{ }^{\circ} \mathrm{C}$ increments to represent $0 \%$ to $100 \%$ injury to blueberry buds (Arora et al., 1997). However, for progressively deacclimating buds (at every 3-d interval for 2000 study or 1-d interval for 2001 study), the treatment temperature ranges representing $0 \%$ to $100 \%$ injury and the temperature increments between the samplings of frozen buds were accordingly adjusted to successively higher (less negative) starting and ending temperatures (for temperature ranges) and to gradually narrowing sampling intervals (for temperature increments) (Table 2). Controls in both years consisted of similarly handled shoots that were kept on ice with no exposure to glycol bath freezing regimes.

Shoots were removed from the freezing bath at the selected treatment temperatures, and samples were allowed to thaw overnight at $4{ }^{\circ} \mathrm{C}$ followed by a 24 -h incubation at $20^{\circ} \mathrm{C}$. Subsequently, buds were dissected and observed for injury (visual browning) of the ovaries in individual flowers (Arora et al., 2000; Flinn and Ashworth, 1994). Buds were rated for 0\% to $100 \%$ browning and $\mathrm{BCH}$ was defined as the temperature causing $50 \%$ injury $\left(\mathrm{LT}_{50}\right)$.

Statistical anAlysis of BCH DATA. For each genotype $\times$ year combination, bootstrap estimates (Manly, 1997) of $\mathrm{LT}_{50}$ values and their $95 \%$ fiducial confidence intervals were calculated

Table 1. Germplasm composition ${ }^{\mathrm{z}}$ of Vaccinium cultivars evaluated for initial bud cold hardiness and deacclimation rates.

\begin{tabular}{lcccc}
\hline Cultivar & V. corymbosum & V. angustifolium & V. darrowi & V. ashei \\
\hline Bluecrop & $93.7 \%$ & $6.3 \%$ & --- & --- \\
Weymouth & $82.5 \%$ & $12.6 \%$ & --- & --- \\
Legacy & $73.4 \%$ & $1.6 \%$ & $25.0 \%$ & --- \\
Ozarkblue & $77.4 \%$ & $3.9 \%$ & $11.3 \%$ & $7.0 \%$ \\
Tifblue & --- & --- & --- & $100.0 \%$
\end{tabular}

${ }^{\mathrm{z}}$ According to Clark et al., 1996; Ehlenfeldt, 1994; Hancock and Sieker, 1982. 
Table 2. Ranges of the treatment temperatures used in the laboratory freeze-thaw test during deacclimation time-course studies of blueberry buds (the same protocol was used for all blueberry cultivars).

\begin{tabular}{lcc}
\hline & \multicolumn{2}{c}{$\begin{array}{c}\text { Range of treatment temperatures } \\
\text { and sampling intervals }\left({ }^{\circ} \mathrm{C}\right)\end{array}$} \\
\cline { 2 - 3 } Treatment & 2000 & 2001 \\
\hline CA $^{\mathrm{z}}(0-\mathrm{DOD})$ & -10 to $-31\left(3{ }^{\circ} \mathrm{C}\right)$ & -10 to $-28\left(2{ }^{\circ} \mathrm{C}\right)$ \\
1-DOD & $\mathrm{ND}$ & -8 to $-26\left(2{ }^{\circ} \mathrm{C}\right)$ \\
2-DOD & $\mathrm{ND}$ & -6 to $-24\left(2^{\circ} \mathrm{C}\right)$ \\
3-DOD & $\mathrm{ND}$ & -4 to $-22\left(2^{\circ} \mathrm{C}\right)$ \\
4-DOD & $\mathrm{ND}$ & -4 to $-22\left(2{ }^{\circ} \mathrm{C}\right)$ \\
5-DOD & -6 to $-18\left(2{ }^{\circ} \mathrm{C}\right)$ & -2 to $-18\left(2{ }^{\circ} \mathrm{C}\right)$ \\
6-DOD & -2 to $-18\left(2{ }^{\circ} \mathrm{C}\right)$ \\
9-DOD & -4 to $-12\left(1^{\circ} \mathrm{C}\right)$ & $\mathrm{ND}$ \\
12-DOD & -3 to $-8\left(0.5^{\circ} \mathrm{C}\right)$ & $\mathrm{ND}$ \\
16-DOD & -2 to $-6\left(0.5^{\circ} \mathrm{C}\right)$ & $\mathrm{ND}$
\end{tabular}

${ }^{2} \mathrm{CA}=$ cold acclimated (sampled from the field in February); DOD $=$ days of deacclimation; ND = not determined.

'Sampling intervals during the freeze test are shown in parentheses.

across days of deacclimation (DOD; 0-, 3-, 6-...16-DOD. or 0-, 1-, 2-...6-DOD etc.) using Proc Probit (SAS, 1999). The nine observed data points (three buds on each of the three shoots) for each temperature were resampled ( $\mathrm{n}=9$ with replacement) 30 times. A sigmoidal (i.e., logistic) regression model was fit to percentage of injury (browning) vs. treatment temperature for each of the 30 sets of resampled data and the 30 resulting values of $\mathrm{LT}_{50}$, and lower and upper confidence limits were averaged to obtain the bootstrap estimates at each DOD. These $\mathrm{LT}_{50}$ estimates were used to evaluate the deacclimation kinetics for each genotype and year of study by fitting a log-linear or asymmetric sigmoidal (Gompertz) model, depending on the genotype, to model the relationship between $\mathrm{LT}_{50}$ and DOD. The $\mathrm{LT}_{50}$ estimates from the models at each DOD and differences in $\mathrm{LT}_{50}$ values between subsequent DOD were compared among genotypes by using analysis of covariance (Milliken and Johnson, 2002).

BUd DEVELOPMENT AND ITS RELATIONSHIP TO BCH. At each sampling for $\mathrm{BCH}$ (i.e., 0-, 1-, 2- 3-...16-DOD), three to five shoots with five to eight floral buds were evaluated for the stage of bud opening. Stages of flower-bud opening were ranked on the scale of $1-7$ as described in Spiers (1978), where $1=$ no visible swelling and $7=$ corollas dropped, and stages $2-6$ define progressively incremental development. Percentage of buds at stages 1-7 was recorded for each DOD sampling. From this, the average bud score for each DOD was calculated. The correlation between bud opening (average bud score) and $\mathrm{BCH}$ values was determined using SAS Proc CORR.

Protein extraction and measurement, SDS-PAGE, AND ANTI-DEHYDRIN IMMUNOBLOTTING. Extraction of bud proteins was performed according to Arora et al. (1997). Protein concentrations of lysates were measured using the method of Esen (1978) as described in Lim et al. (1999). SDS-PAGE of bud proteins and their anti-dehydrin immunoblotting were carried out as described in Arora et al. (1997).

\section{Results and Discussion}

COMPARISON OF COLD ACCLIMATED BCH AND DEACCLIMATION KINETICS OF BLUEBERRY CULTIVARS. Levels of BCH during the deacclimation study of 2000 indicated that 'Bluecrop' and 'Weymouth' were hardier than 'Tifblue' at the beginning of the
Table 3. Bud cold hardiness of flower buds at 0- to 16-DOD for three blueberry cultivars in 2000 .

\begin{tabular}{lcccccc}
\hline & \multicolumn{5}{c}{ Bud cold hardiness $\left({ }^{\circ} \mathrm{C}\right)$} \\
\cline { 2 - 7 } Cultivar & $\mathrm{CA}^{\mathrm{z}}$ & 3-DOD & 6-DOD & 9-DOD & 12-DOD & $16-D O D$ \\
\hline Bluecrop & $-25.7 \mathrm{a}^{\mathrm{y}}$ & $-18.6 \mathrm{a}$ & $-12.1 \mathrm{a}$ & $-8.2 \mathrm{a}$ & $-6.9 \mathrm{a}$ & $-5.0 \mathrm{a}$ \\
Weymouth & $-25.6 \mathrm{a}$ & $-17.5 \mathrm{a}$ & $-11.8 \mathrm{a}$ & $-9.3 \mathrm{a}$ & $-7.9 \mathrm{a}$ & $-4.7 \mathrm{a}$ \\
Tifble & $-21.2 \mathrm{~b}$ & $-11.2 \mathrm{~b}$ & $-8.7 \mathrm{~b}$ & $7.7 \mathrm{a}$ & $-7.1 \mathrm{a}$ & $-6.0 \mathrm{a}$ \\
\hline
\end{tabular}

${ }^{2} \mathrm{CA}=$ cold acclimated (or at 0 -DOD); DOD = days of deacclimation y Mean separation among cultivars within columns determined by $95 \%$ fiducial confidence limits.

deacclimation program (CA or 0-DOD) (Table 3). These results are in accordance with earlier reports on the levels of 'Bluecrop' and 'Tifblue' $\mathrm{BCH}$ evaluated using similar protocols (Arora et al., 1997; Muthalif and Rowland, 1994). No prior study has systematically examined BCH of 'Weymouth'. However, based on its northern germplasm composition, it is expected to be hardier than 'Tifblue' and to have BCH similar to that of 'Bluecrop'. Our data support this notion. Data also indicated that all the cultivars showed a substantial drop in BCH (28\% for 'Bluecrop', $32 \%$ for 'Weymouth', and 47\% for 'Tifblue') within $3 \mathrm{~d}$ of exposure to our deacclimation regime (constant $20^{\circ} \mathrm{C}$ ). Moreover, by 6-DOD, all cultivars had lost more than $50 \%$ of their cold-acclimated BCH with 'Tifblue' losing the most at $\approx 59 \%$. At the end of 6DOD, 'Bluecrop' and 'Weymouth' buds were still hardier than 'Tifblue' buds. However, by 9-DOD all cultivars had reached about the same level of $\mathrm{BCH}\left(-7.7\right.$ to $\left.-9.3^{\circ} \mathrm{C}\right)$. Thus, treatment of 9-DOD or more appears to override the initial differences in cold-acclimated $\mathrm{BCH}$ of the cultivars. Although deacclimation continued throughout the course of this study, and the $\mathrm{BCH}$ for all the cultivars reached about -5 to $-6^{\circ} \mathrm{C}$ by 16 -DOD, the drop in $\mathrm{BCH}$ at each 3-d interval from 6-DOD onwards was less than during the first $6 \mathrm{~d}$ of treatment. Finally, all the cultivars lost a similar amount of their cold acclimated BCH (72\% to $82 \%)$ by 16-DOD.

Log-linear deacclimation models, fit to the $\mathrm{BCH}$ vs. DOD data and the actual observed $\mathrm{BCH}$ values for the three genotypes in the 2000 study are shown in Fig. 1. Losses in $\mathrm{BCH}$ for every 3-d time interval and rates of deacclimation (losses in $\mathrm{BCH}$ per day for each interval) predicted from the deacclimation models were also determined (Table 4). The largest loss in $\mathrm{BCH}$ and the fastest rate of deacclimation occurred between 0- and 3-DOD for all three genotypes. During this time interval, 'Tifblue' lost significantly more of its initial $\mathrm{BCH}, 11.2^{\circ} \mathrm{C}$ or $\approx 51 \%$, than did 'Bluecrop' or 'Weymouth', both of which lost about $8.6^{\circ} \mathrm{C}$ or $\approx 33 \%$ of their initial values. Therefore, the faster deacclimator during this first 3-d interval was 'Tifblue'. Deacclimation rates for all three genotypes appeared to slow markedly as they reached a BCH level of about -11 to $-13^{\circ} \mathrm{C}$ (Fig. 1, Table 4). Thus, between 3- and 6-DOD and between 6- and 9-DOD, the rate of deacclimation of 'Tifblue', which had already reached a BCH level of $-10.8^{\circ} \mathrm{C}$ by $3-\mathrm{DOD}$, declined sharply to about one-third the rate of deacclimation of 'Bluecrop' and 'Weymouth' during this same time frame. Between 9- and 12-DOD and beyond, there was no difference in the loss in $\mathrm{BCH}$ among the genotypes, as the rate of deacclimation had declined in all to $<1{ }^{\circ} \mathrm{C}$ per day.

In the year 2000 study, deacclimation occurred quickly at 20 ${ }^{\circ} \mathrm{C}$ and appeared to plateau for all cultivars by about 6-DOD. Therefore, the deacclimation study undertaken in 2001 focused on this critical 6-d period. Five blueberry cultivars (three cultivars as in the year 2000 study plus 'Legacy' and 'Ozarkblue', which 
Fig. 1. Deacclimation of three blueberry cultivars from 0-DOD (days of deacclimation) through 16-DOD in 2000. Curves show the bud cold hardiness $(\mathrm{BCH})$ values predicted from log-linear models. Points represent observed values. The log-linear models, which describe $\mathrm{BCH}$ values (y) as a function of DOD (x), are of the general form: $\mathrm{BCH}$ $=\mathrm{a}+\mathrm{b} \times \log _{\mathrm{e}}(\mathrm{DOD}+\mathrm{c})$. The relationship of BCH to DOD for 'Bluecrop' (BC) and 'Weymouth'(WY) was described by identical predictive model: $\mathrm{BCH}=-34.24+10.22 \times$ $\log _{\mathrm{e}}(\mathrm{DOD}+2.29)$. For 'Tifblue' (TB), the relationship of $\mathrm{BCH}$ to $\mathrm{DOD}$ was described by the equation: $\mathrm{BCH}=-13.31+2.29 \times$ $\log _{\mathrm{e}}(\mathrm{DOD}+0.02)$.

have some southern germplasm in their backgrounds but less than that of 'Tifblue') were deacclimated for increasing 1-d intervals up to $6 \mathrm{~d}$. Levels of BCH during the 2001 study are presented in Table 5. Results indicated that 'Bluecrop' and 'Weymouth' were the hardiest at 0-DOD, followed by 'Ozarkblue', 'Tifblue', and 'Legacy'. By 1-DOD, the BCH of 'Bluecrop' and 'Weymouth' had changed very little, whereas $\mathrm{BCH}$ of 'Legacy' and 'Ozarkblue' had dropped by 2.3 and $3.2^{\circ} \mathrm{C}$, respectively, and that of 'Tifblue' had dropped by $5.6^{\circ} \mathrm{C}$. By 2-DOD, BCH of all the cultivars, except 'Bluecrop' (confidence limits still overlapped with those at 0-DOD), had dropped significantly from the 0-DOD level. By 3-DOD, BCH had dropped significantly for all the cultivars, by 22\% for 'Bluecrop', 27\% for 'Weymouth', 27\% for 'Legacy', 29\% for 'Ozarkblue', and 39\% for 'Tifblue'. This was similar to the drop seen in 2000 by 3-DOD (average loss of about 29\% in 2001 as compared to $36 \%$ in 2000). By 6-DOD, the average loss in $\mathrm{BCH}$ was about $40 \%$ as compared to $55 \%$ in the 2000 . At this time-point, 'Weymouth', 'Bluecrop', and 'Legacy' were hardier ('Weymouth' being significantly so) than 'Ozarkblue' and 'Tifblue'. To determine if there was a difference in deacclimation response between years, an ANOVA was performed on the $\mathrm{BCH}$ data for the $3 \mathrm{~d}$ and the three genotypes that were in common between the 2 years; no significant difference between years was found.

Deacclimation models, log-linear for 'Weymouth', 'Ozarkblue', and 'Tifblue', and Gompertz for 'Bluecrop' and 'Legacy', fit to the BCH vs. $\mathrm{DOD}$ data and the actual observed $\mathrm{BCH}$ values for the year 2001 study are shown in Fig. 2. Changes in $\mathrm{BCH}$ for each day during the 6-d period (= rates of deacclimation for each 1-d time interval) predicted from the deacclimation models are shown in Table 6. Because we did not consider differences of $<2{ }^{\circ} \mathrm{C}$ biologically significant, only the losses in $\mathrm{BCH}$ by 1-DOD showed significant differences among the cultivars. By 1-DOD, 'Tifblue' had lost the most BCH, decreasing $5.7^{\circ} \mathrm{C}$, making it the fastest deacclimator

\section{Year 2000 Study}

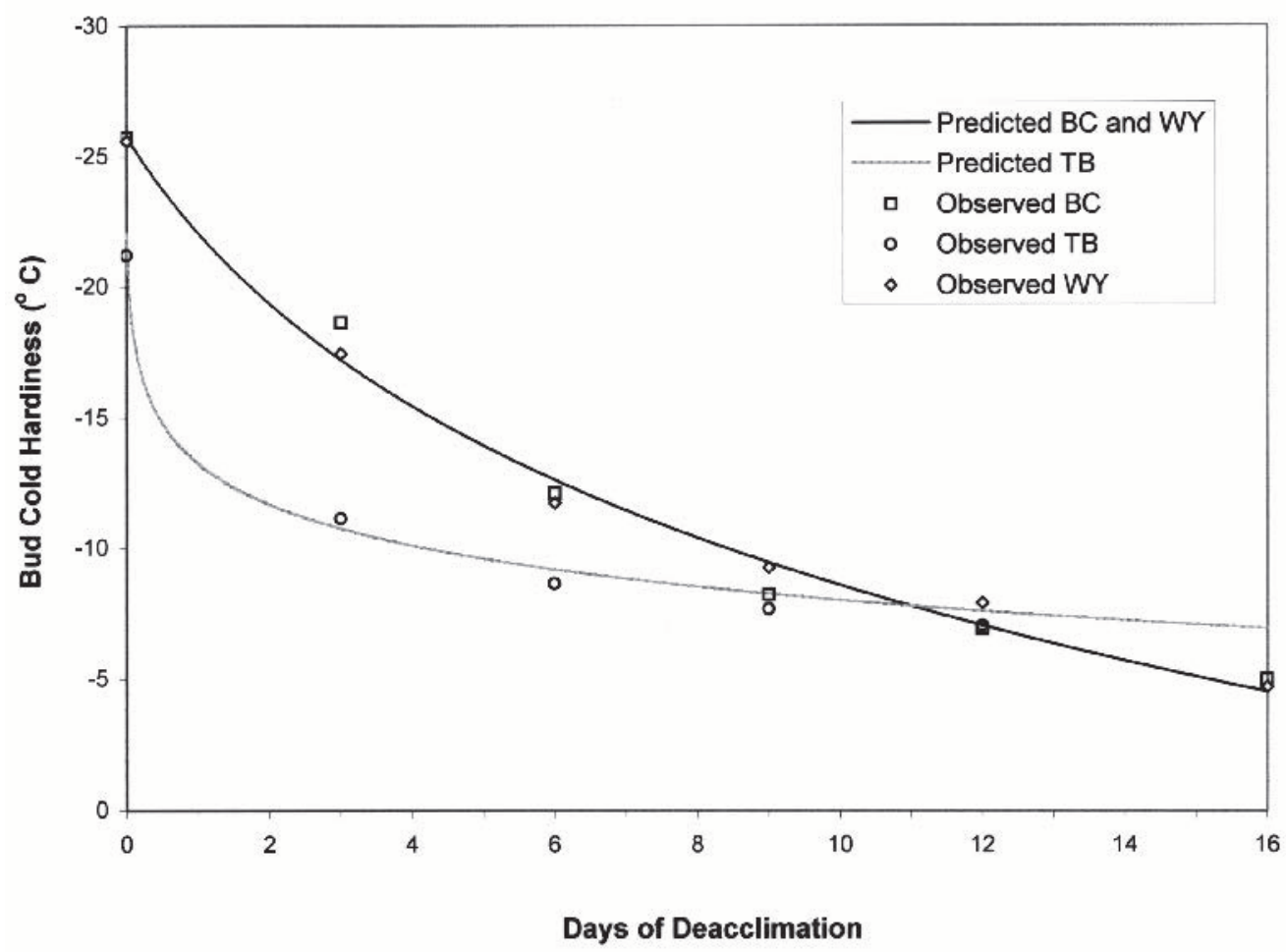

Table 4. Changes in bud cold hardiness $\left({ }^{\circ} \mathrm{C}\right)$ and rates of change $\left({ }^{\circ} \mathrm{C} \cdot \mathrm{d}^{-1}\right)$ from deacclimation models generated for three blueberry cultivars in 2000 .

\begin{tabular}{lcccccc}
\hline & \multicolumn{5}{c}{$\begin{array}{c}\text { Loss of cold hardiness about every 3 DOD }\left({ }^{\circ} \mathrm{C}\right) \\
\text { and rate of deacclimation }\left({ }^{\circ} \mathrm{C} \cdot \mathrm{d}^{-1}\right)^{\mathrm{z}}\end{array}$} \\
\cline { 2 - 7 } Cultivar & CA & 3-DOD & 6-DOD & 9-DOD & 12-DOD & 16-DOD \\
\hline BC & $-25.8 \mathrm{a}^{\mathrm{x}}$ & $8.6 \mathrm{a}(2.9)^{\mathrm{z}}$ & $4.6 \mathrm{~b}(1.5)$ & $3.1 \mathrm{~b}(1.0)$ & $2.4 \mathrm{a}(0.8)$ & $2.6 \mathrm{a}(0.7)$ \\
WY & $-25.8 \mathrm{a}$ & $8.6 \mathrm{a}(2.9)$ & $4.6 \mathrm{~b}(1.5)$ & $3.1 \mathrm{~b}(1.0)$ & $2.4 \mathrm{a}(0.8)$ & $2.6 \mathrm{a}(0.7)$ \\
$\mathrm{TB}$ & $-22.0 \mathrm{~b}$ & $11.2 \mathrm{~b}(3.7)$ & $1.6 \mathrm{a}(0.5)$ & $0.9 \mathrm{a}(0.3)$ & $0.7 \mathrm{a}(0.2)$ & $0.6 \mathrm{a}(0.2)$ \\
\hline
\end{tabular}

${ }^{2}$ Rates of deacclimation at each time interval (shown in parentheses) are the loss in bud cold hardiness per day for that 3 -d period.

y $\mathrm{BC}=$ 'Bluecrop'; WY = 'Weymouth'; TB = 'Tifblue'; CA = cold acclimated (or at 0 -DOD); DOD = days of deacclimation.

xMean separation among cultivars within columns determined by analysis of covariance.

Table 5. Bud cold hardiness of flower buds at 0- to 6-DOD for five blueberry cultivars in 2001 .

\begin{tabular}{lccccccc}
\hline & \multicolumn{7}{c}{ Bud cold hardiness $\left({ }^{\circ} \mathrm{C}\right)$} \\
\cline { 2 - 8 } Cultivar $^{z}$ & CA & 1-DOD & 2-DOD & 3-DOD & 4-DOD & 5-DOD & 6-DOD \\
\hline BC & $-23.6 \mathrm{a}$ & $-24.5 \mathrm{a}$ & $-20.6 \mathrm{a}$ & $-18.3 \mathrm{a}$ & $-17.3 \mathrm{a}$ & $-13.7 \mathrm{ab}$ & $-13.6 \mathrm{ab}$ \\
WY & $-23.0 \mathrm{ab}$ & $-22.4 \mathrm{a}$ & $-18.8 \mathrm{a}$ & $-16.8 \mathrm{ab}$ & $-15.5 \mathrm{a}$ & $-15.4 \mathrm{a}$ & $-14.3 \mathrm{a}$ \\
LG & $-18.7 \mathrm{c}$ & $-16.4 \mathrm{~b}$ & $-14.3 \mathrm{bc}$ & $-13.6 \mathrm{~cd}$ & $-12.8 \mathrm{~b}$ & $-12.4 \mathrm{ab}$ & $-12.8 \mathrm{ab}$ \\
OB & $-20.4 \mathrm{bc}$ & $-17.2 \mathrm{~b}$ & $-15.3 \mathrm{~b}$ & $-14.5 \mathrm{bc}$ & $-14.4 \mathrm{ab}$ & $-11.8 \mathrm{~b}$ & $-11.5 \mathrm{~b}$ \\
TB & $-19.0 \mathrm{c}$ & $-13.4 \mathrm{c}$ & $-12.4 \mathrm{c}$ & $-11.6 \mathrm{~d}$ & $-10.0 \mathrm{c}$ & $-11.5 \mathrm{~b}$ & $-11.2 \mathrm{~b}$
\end{tabular}

"BC = 'Bluecrop'; WY = 'Weymouth'; LG = 'Legacy'; OB = 'Ozarkblue'; TB = 'Tifblue'; $\mathrm{CA}=$ cold acclimated ( or at 0 -DOD); DOD = days of deacclimation yMean separation among cultivars within columns determined by $95 \%$ fiducial confidence limits. 


\section{Year 2001 Study}

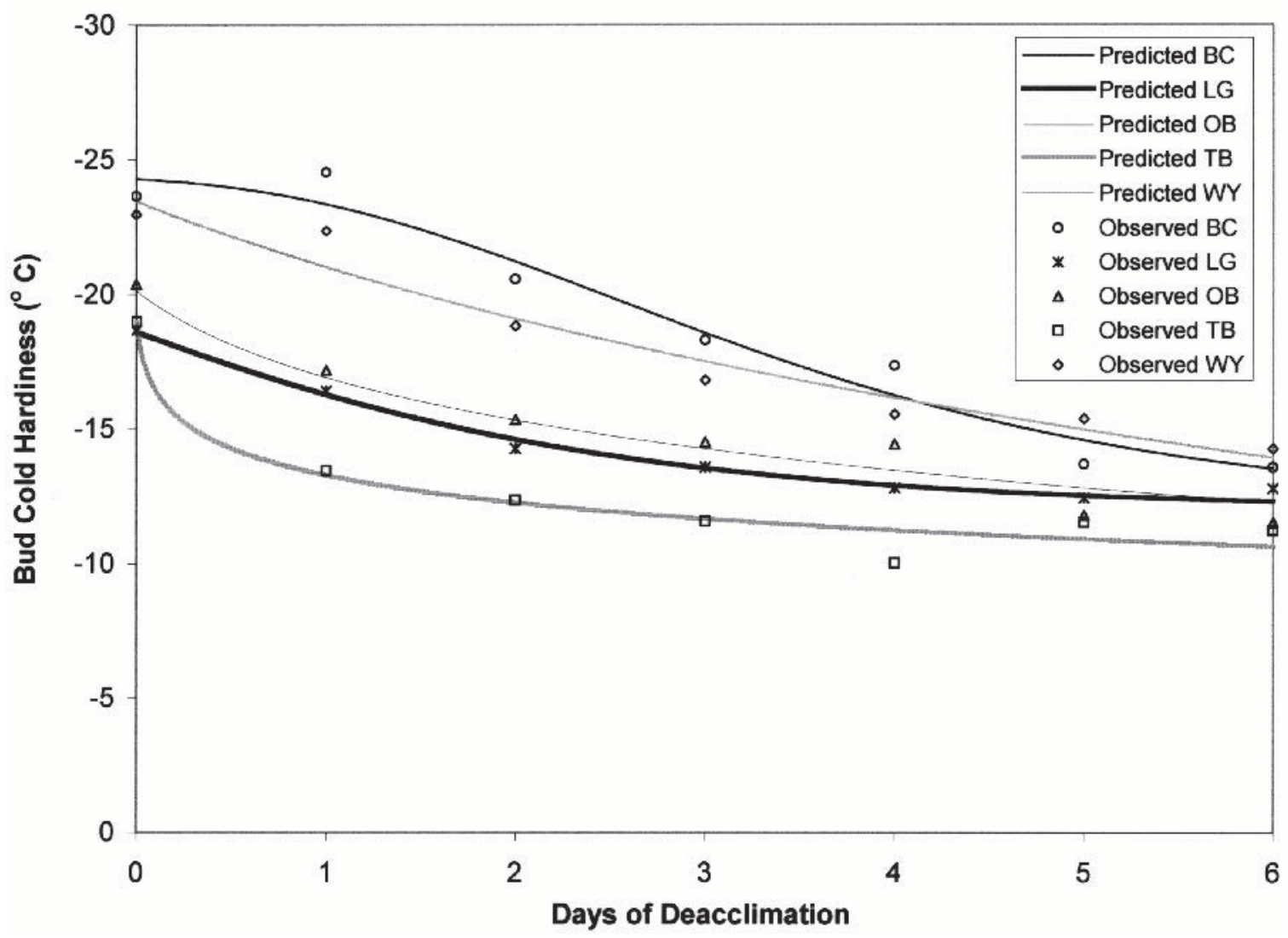

Fig. 2. Deacclimation of five blueberry cultivars from 0-DOD (days of deacclimation) through 6-DOD in 2001. Curves show the bud cold hardiness (BCH) values predicted from log-linear ['Weymouth' (WY), 'Ozarkblue' (OB), and 'Tifblue' (TB)] or Gompertz ['Bluecrop' (BC) and 'Legacy' (LG)] models. Points represent observed values. Models that describe $\mathrm{BCH}$ values $(\mathrm{y})$ as a function of $\mathrm{DOD}(\mathrm{x})$ are of the general form: $\mathrm{BCH}=\mathrm{a}+\mathrm{b} x \log \mathrm{e}(\mathrm{DOD}+\mathrm{c})(\log -\operatorname{linear})$ and $\mathrm{BCH}=\mathrm{d}$ $+\mathrm{a} \times \exp [-\exp (\mathrm{b}-\mathrm{c} \times \mathrm{DOD})]($ Gompertz). The specific predictive models are:

Log-linear

'Weymouth': $\mathrm{BCH}=-34.24+9.13 \times \log _{\mathrm{e}}(\mathrm{DOD}+3.26)$

'Ozarkblue': $\mathrm{BCH}=-18.42+3.26 \times \log _{\mathrm{e}}(\mathrm{DOD}+0.59)$

'Tiblue': $\mathrm{BCH}=-13.31+1.48 \times \log _{\mathrm{e}}(\mathrm{DOD}+0.02)$

Gompertz

'Bluecrop': $\mathrm{BCH}=-24.43+12.38 \times \exp [-\exp (1.48-0.59 \times \mathrm{DOD})]$

'Legacy': $\mathrm{BCH}=-24.43+12.38 \times \exp [-\exp (-0.28-0.59 \times \mathrm{DOD})]$

Table 6. Changes in bud cold hardiness $(\mathrm{BCH})$ every one DOD $\left({ }^{\circ} \mathrm{C}\right)[=$ rates of deacclimation $\left.\left({ }^{\circ} \mathrm{C} \cdot \mathrm{d}^{-1}\right)\right]$ from deacclimation models generated for the five blueberry cultivars in 2001 .

\begin{tabular}{lccccccc}
\hline & \multicolumn{6}{c}{ Loss in $\mathrm{BCH}$ every one DOD $\left({ }^{\circ} \mathrm{C}\right)\left[=\right.$ rate of deacclimation $\left.\left({ }^{\circ} \mathrm{C} \cdot \mathrm{d}^{-1}\right)\right]$} \\
\cline { 2 - 7 } Cultivar $^{z}$ & CA & 1-DOD & 2-DOD & 3-DOD & 4-DOD & 5-DOD & 6-DOD \\
\hline BC & $-24.3 \mathrm{a} y$ & $0.9 \mathrm{a}$ & $2.2 \mathrm{a}$ & $2.6 \mathrm{a}$ & $2.4 \mathrm{a}$ & $1.6 \mathrm{a}$ & $1.1 \mathrm{a}$ \\
WY & $-23.5 \mathrm{a}$ & $2.5 \mathrm{ab}$ & $1.9 \mathrm{a}$ & $1.6 \mathrm{a}$ & $1.3 \mathrm{a}$ & $1.2 \mathrm{a}$ & $1.1 \mathrm{a}$ \\
LG & $-18.6 \mathrm{~b}$ & $2.3 \mathrm{ab}$ & $1.7 \mathrm{a}$ & $1.1 \mathrm{a}$ & $0.6 \mathrm{a}$ & $0.4 \mathrm{a}$ & $0.2 \mathrm{a}$ \\
OB & $-20.1 \mathrm{~b}$ & $3.2 \mathrm{~b}$ & $1.6 \mathrm{a}$ & $1.0 \mathrm{a}$ & $0.8 \mathrm{a}$ & $0.7 \mathrm{a}$ & $0.5 \mathrm{a}$ \\
$\mathrm{TB}$ & $-19.0 \mathrm{~b}$ & $5.7 \mathrm{c}$ & $1.0 \mathrm{a}$ & $0.6 \mathrm{a}$ & $0.5 \mathrm{a}$ & $0.3 \mathrm{a}$ & $0.3 \mathrm{a}$
\end{tabular}

zBC = 'Bluecrop'; WY = 'Weymouth'; LG = 'Legacy'; OB = 'Ozarkblue'; TB = 'Tifblue'; $\mathrm{CA}=$ cold acclimated (or at 0-DOD); DOD = days of deacclimation.

y Mean separation among cultivars within columns determined by analysis of covariance.

of all the cultivars tested. By 2-DOD, its rate of deacclimation had slowed considerably. By 1-DOD, 'Bluecrop' had changed the least, losing $<1{ }^{\circ} \mathrm{C}$ of $\mathrm{BCH}$, making it a slow deacclimator. By 2DOD, however, its deacclimation had begun, and it continued to lose $2.2-2.6^{\circ} \mathrm{C}$ of $\mathrm{BCH}$ each day for the next $3 \mathrm{~d}$, at which point its rate of deacclimation slowed. 'Ozarkblue' was intermediate in deacclimation, losing $3.2^{\circ} \mathrm{C}$ of $\mathrm{BCH}$ by 1-DOD, more than
'Bluecrop' and less than 'Tifblue'. 'Weymouth', and 'Legacy' were slow to intermediate deacclimators, losing 2.3 to $2.5^{\circ} \mathrm{C}$ of $\mathrm{BCH}$ by $1-\mathrm{DOD}$, which was not different from either 'Bluecrop' or 'Ozarkblue'.

From these studies, cultivar differences in deacclimation response were clearly evident. The $V$. ashei 'Tifblue' was the fastest deacclimator and $V$. corymbosum 'Bluecrop' one of the slowest. 'Ozarkblue', which is $7 \%$ V. ashei and $11 \%$ V. darrowi, was intermediate, and 'Weymouth' (mainly V. corymbosum) and 'Legacy' (25\% V. darrowi) were slow to intermediate. Thus, germplasm composition suggests that the southern component, in particular V. ashei, may be responsible for the faster deacclimation of 'Tifblue' and 'Ozarkblue'. Of course, the observed cultivar differences in response to a controlled deacclimation regime may not necessarily translate into similar differences under field conditions with diurnal cycling from warm days to relatively cooler (or even sub-freezing) temperatures in the night that might serve to maintain hardiness due to potential quick reacclimation response. Experiments are currently under way to study the fielddeacclimation response in several blueberry cultivars. 
Cultivars used in this study also vary in their chilling requirements (CRs), which begs the question: does this have any impact on respective rates of deacclimation? The two V. corymbosum cultivars Bluecrop and Weymouth, which were also the most cold hardy at fully acclimated state, have CR of $\approx 1000$ chill-hours (Muthalif and Rowland, 1994; L.J. Rowland, personal communication) and were classified in our study as high chill requiring. 'Ozarkblue', part V. ashei and part V. darrowi germplasm with CR of $\approx 800$ chill-hours (Clark et al., 1996) was ranked as an intermediate chill-requiring cultivar and was also intermediate hardy. And the two least hardy cultivars, 'Tifblue' and 'Legacy', have CR of $\approx 600$ chill-hours (Muthalif and Rowland, 1994) and 500 chill-hours (J.R. Clark, personal communication), respectively. All the cultivars were subjected to the deacclimation treatments simultaneously, which was only after their CRs had been met. It is noteworthy, however, that under our experimental protocol, the low chill-requiring cultivars would have been exposed to greater number of chill-hours by 0-DOD than those with higher CRs. Results from this study indicate that the CRs and cold acclimated hardiness in the five cultivars are positively correlated, in that the cultivars with higher CRs exhibit greater bud hardiness at 0-DOD, and support our earlier observations (Arora et al., 1997). However, due to the lack of a consistent trend, no definitive conclusions could be drawn about the relationship between the CR and the rate of deacclimation, if any, of the buds of five blueberry cultivars. Moreover, differential exposure to number of chill-hours beyond their respective CRs also did not seem to have any consistent influence on the rate of deacclimation under our experimental conditions.

Previous research has demonstrated that provenance has significant impact on the cold hardiness of plants. For example, Lindstrom and Dirr (1989) reported that two northern selections of Acer rubrum L. (red maple) acclimated at faster rates and attained greater degrees of cold hardiness than two southern selections. Similarly, provenance also influences the timing of growth cessation in the fall, a phenomenon closely associated with the onset of cold acclimation (Pauley and Perry, 1954). But, whether or how the latitudinal origin or northern vs. southern ancestry of a given cultivar impacts the kinetics of deacclimation has not been well investigated. Data from our controlled-deacclimation study, although limited in its scope, suggest that the slow deacclimation trait in blueberry buds may be associated with the northern ancestry of a cultivar and that the fast deacclimation trait may be associated with some southern species but not necessarily all. How these cultivars respond to natural spring deacclimation or to a transient mid-winter warm spell should be a topic of future studies.

Our results also suggest that deacclimation rates are not necessarily related to mid-winter bud hardiness in these cultivars. At first glance, it appears that they are correlated. For 'Bluecrop', 'Weymouth', 'Ozarkblue', and 'Tifblue', the hardier the cultivar, the slower it appears to deacclimate. However, upon closer inspection, some exceptions become evident. For example, 'Legacy' has about the same level of mid-winter hardiness as 'Tifblue', but it does not deacclimate as quickly as 'Tifblue'. The association between mid-winter bud hardiness and deacclimation rate probably depends on the genotypes/species that are involved. Again, evidence suggests that the southern species V.ashei may contribute genes determining cold sensitivity and fast deacclimation while the southern species $V$. darrowi may contribute only genes for cold sensitivity. Lindstrom and Dirr (1991) reported that some of the most mid-winter-hardy cultivars of Ulmus parvifolia Jacq (chinese elm) were not always the most hardy during dehardening in spring. These authors, however, did not employ a laboratorycontrolled regime of deacclimation as was used in our study. Wolf and Cook (1992) exposed fully acclimated Vitis L. buds to a controlled deacclimation regime $\left(23^{\circ} \mathrm{C}\right)$ and noted that 'Concord', the most hardy cultivar examined, typically demonstrated the most rapid rate of deacclimation, whereas 'Cabernet Sauvignon', the least hardy cultivar, was most resistant to deacclimation. A recent study of controlled deacclimation in several Solanum L. species demonstrated that the rates of deacclimation were not related to the acclimation capacity of these species (Vega et al., 2000).

Previous genetic studies of cold hardiness of Rhododendron L. (Lim et al., 1998) and Solanum (Stone et al., 1993) have shown that the two components of mid-winter hardiness, 1) non-acclimated freezing tolerance, and 2) cold acclimation capacity (the difference between cold acclimated and non-acclimated hardiness), are under separate genetic control. These authors, therefore, suggested that these two components could be selected for independently in a breeding program. Results from our study demonstrate that, in addition, genotypes may exhibit variability in deacclimation response, independent from their mid-winter hardiness. Rate and the extent of deacclimation in the early spring or during transient warm periods of winter are among the key factors determining winter survival of reproductive apices of woody plants (Pellett, 1998). Ideally, blueberry growers in harsh climates would want cultivars that acclimate quickly but resist deacclimation during transient warm spells. Rate of deacclimation should, therefore, be considered in a breeding program aimed at improving winter survival.

Bud Development And deacclimation. To determine if the stage of bud opening during a warm spell (after the completion of endodormancy) could be used as an indicator of the level of $\mathrm{BCH}$, we examined the time course of bud opening in the progressively deacclimating buds of the three blueberry cultivars in the 2000 study (Table 7) and the five cultivars in the 2001 study (Table 8). In 2000, 'Bluecrop' and 'Weymouth' flower buds initially were fairly tightly closed with no to little visible swelling at 0-DOD (average bud stages of 1.0 and 1.5, respectively). They became progressively more developed during the deacclimation regime, reaching stages of 3.7 and 4.3, respectively, by 16-DOD. 'Tifblue' buds began as more swollen, average bud stage of 2.0, and reached a stage of 3.1 by 16-DOD. In 2001, flower buds of all cultivars began as tightly closed (average bud stages of 1.0-1.1) and reached stages of 1.5-2.0 by 6-DOD, with 'Ozarkblue' and 'Tifblue' being slightly more advanced (2.0) than 'Bluecrop' (1.5), 'Weymouth' (1.8), or 'Legacy' (1.75). Highly significant positive correlations were found between stage of bud opening

Table 7. Average stage of bud development from 0- to 16-DOD (at constant $20^{\circ} \mathrm{C}$ ) for three blueberry cultivars in 2000 .

\begin{tabular}{lcccccc}
\hline & \multicolumn{5}{c}{ Avg score for stage of bud development ${ }^{z}$} \\
\cline { 2 - 7 } Cultivar & CAy & 3-DOD & 6-DOD & 9-DOD & 12-DOD & 16-DOD \\
\hline Bluecrop & 1.00 & 1.75 & 2.30 & 2.65 & 3.10 & 3.70 \\
Weymouth & 1.50 & 1.60 & 2.60 & 3.10 & 3.65 & 4.30 \\
Tifblue & 2.00 & 2.20 & 2.60 & ND & 3.10 & 3.10 \\
\hline
\end{tabular}

${ }^{ }$Stages of bud development: 1 = no visible swelling; $2=$ visible swelling of bud (green tip seen); 3 = bud scales separated, apices of flowers visible; 4 = individual flowers distinguishable, bud scales abscised; 5 = individual flowers distinctly separated, corollas unexpanded and enclosed; $6=$ corollas completely expanded and open; $7=$ corollas dropped (Spiers, 1978).

${ }^{\mathrm{y} C A}=$ cold acclimated (or at $0-\mathrm{DOD}$ ); $\mathrm{DOD}=$ days of deacclimation; $\mathrm{ND}=$ not determined 
Table 8. Average stage of bud development from 0- to 6-DOD (at constant $20{ }^{\circ} \mathrm{C}$ ) for five blueberry cultivars in 2001.

\begin{tabular}{lccccccc}
\hline & \multicolumn{7}{c}{ Avg score for stage of bud development } \\
\cline { 2 - 7 } Cultivar & CA $^{\mathrm{x}}$ & 1-DOD & 2-DOD & 3-DOD & 4-DOD & 5-DOD & 6-DOD \\
\hline BC & 1.00 & 1.00 & 1.30 & 1.25 & 1.30 & 1.40 & 1.50 \\
WY & 1.00 & 1.00 & 1.00 & 1.00 & 1.30 & 1.50 & 1.80 \\
LG & 1.00 & 1.05 & 1.70 & 1.40 & 1.75 & 1.50 & 1.75 \\
OB & 1.00 & 1.00 & 1.30 & 1.40 & 1.75 & 1.70 & 2.00 \\
TB & 1.10 & 1.10 & 1.90 & 2.00 & 1.95 & 1.90 & 2.00
\end{tabular}

${ }^{\text {SStage of bud development: } 1 \text { = no visible swelling; } 2 \text { = visible swelling of bud (green }}$ tip seen); 3 = bud scales separated, apices of flowers visible; 4 = individual flowers distinguishable, bud scales abscised; 5 = individual flowers distinctly separated, corollas unexpanded and enclosed; $6=$ corollas completely expanded and open; $7=$ corollas dropped (Spiers, 1978).

уBC = 'Bluecrop'; WY = 'Weymouth'; LG = 'Legacy'; OB = 'Ozarkblue'; TB = 'Tifblue'; $\mathrm{CA}=$ cold acclimated at 0-DOD.

${ }^{\times} \mathrm{CA}=$ cold acclimated (or at 0-DOD); DOD = days of deacclimation.

and BCH in both years $(r=0.90$ in 2000 and $r=0.82$ in 2001, $P$ $<0.0001$ in both years). Although intuitively one would expect more-open flower buds to be more vulnerable to freeze damage than tightly closed ones because of the presence of tender, new growth, this is not the case for all plants. Several filbert (Corylus L.) genotypes have fully open flowers in December and January that are cold hardy to -30 to $-40{ }^{\circ} \mathrm{C}$ (Hummer et al., 1986).

DEHYDRIN METABOLISM AND DEACCLIMATION. Dehydrin proteins and their transcripts accumulate during seasonal CA in bark, xylem, buds, shoot apices, and in seedlings of woody plants (Svensson et al., 2002, and references therein). Because of their hydrophilic properties and presence of amphipathic peptide domains within their structure, they are believed to interact with endomembranes and protect them and cellular proteins from the destabilizing effects of sub-zero temperatures and/or freeze-induced desiccation (reviewed by Close, 1996, and Svensson et al., 2002). Adefinitive in vivo role of dehydrins in planta has not been demonstrated as yet; however, several in vitro and immunolocalization studies have demonstrated their role in cryoprotection of proteins (Wisniewski et al., 1999), propensity for hydrophobic interactions (Ceccardi et al., 1994), ability to bind lipid vesicles (Koag et al., 2003), and localization close to the plasma membrane (Danyluk et al., 1998), all of which support their potential role in stabilizing cells under cold stress.

Muthalif and Rowland (1994) first identified three major dehydrins (65-, 60-, and 14-kDa) in blueberry floral buds whose levels increase during seasonal development of BCH. Subsequently, Arora et al. (1997) noted that the differences in $\mathrm{BCH}$ among three blueberry cultivars ('Bluecrop', the most hardy; 'Tifblue', intermediately hardy; and 'Gulfcoast', the least hardy) were positively correlated with the accumulation of 65-, 60-, and 14-kDa dehydrins. These authors further demonstrated that dehydrin metabolism in these buds was more specifically associated with changes in $\mathrm{BCH}$ rather than dormancy transitions that coincide with acclimation-deacclimation cycles.

Results from the present study confirm our earlier findings that indeed the hardier cultivars ('Bluecrop' and 'Weymouth'; Tables 3 and 5) accumulate higher levels of these dehydrins (based on visual estimates) than the less hardy 'Tifblue'(Fig. 3). Additionally, we found that the step-wise loss of $\mathrm{BCH}$ during a controlled deacclimation regime was accompanied by a progressive down-regulation of these dehydrins (Fig. 3). However, patterns of their down-regulation differed remarkably. For example, the $60-\mathrm{kDa}$ dehydrin appears the most stable during deacclimation, as it was detected even in the 16-DOD samples of 'Weymouth' and 'Tifblue' when they retained only $\approx 20 \%$ and $\approx 30 \%$ of their 0 -DOD BCH, respectively. The $65-\mathrm{kDa}$ dehydrin appears to have a similar rate of decline but to begin at a lower level than that of the $60 \mathrm{kDa}$ dehydrin. The 14-kDa dehydrin, on the other hand, appears to be the least stable during deacclimation and to be down-regulated most rapidly in 'Tifblue' (completely disappeared by 3-DOD), followed by 'Weymouth' (faintly visible at 3-DOD) and then in 'Bluecrop', where it was detected up to 6DOD although at substantially lower levels compared to at 0-DOD. Therefore, of the three dehydrins, the down-regulation kinetics of only the $14 \mathrm{kDa}$ dehydrin closely parallels the deacclimation dynamics (discussed above) of blueberry cultivars: 'Tifblue', the fastest deacclimator, 'Weymouth', an intermediate one, and

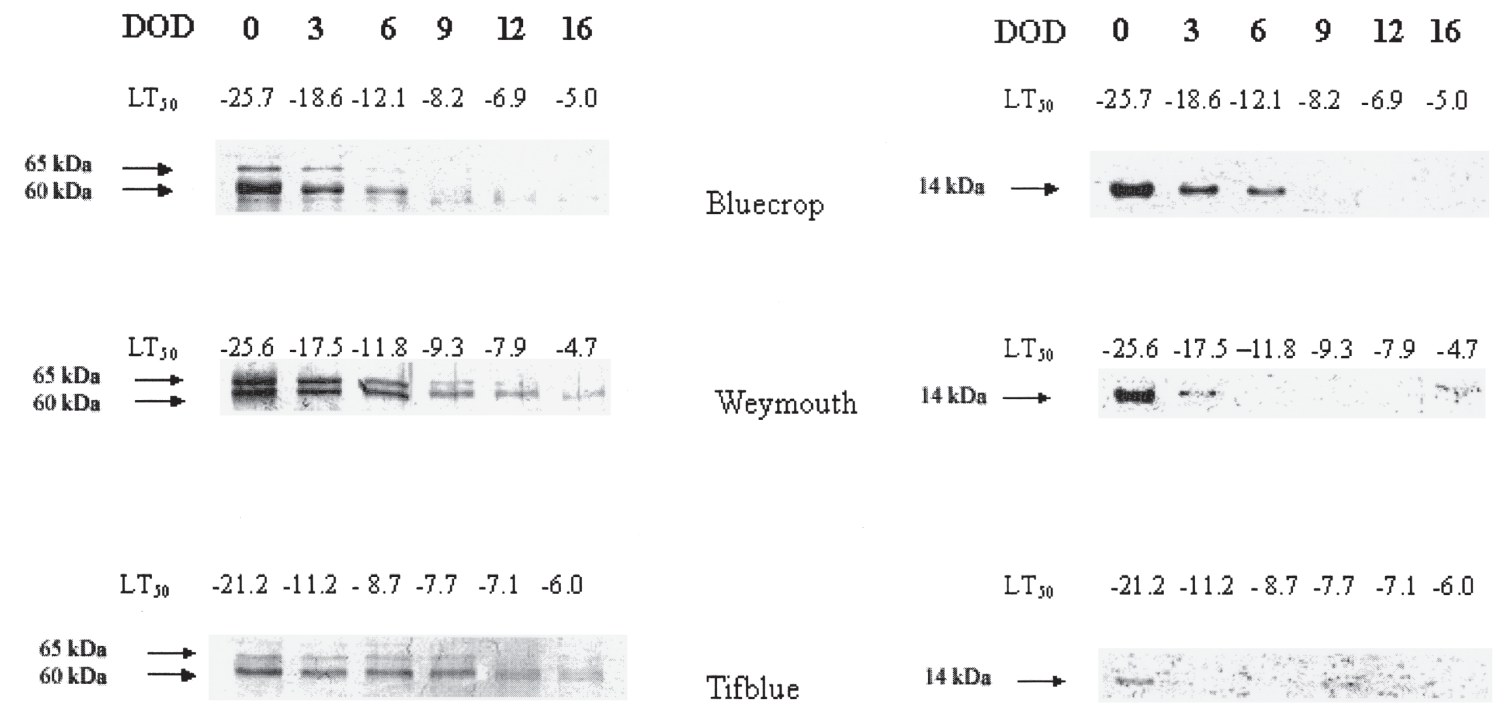

Fig. 3. Western blot analyses of floral bud proteins from three blueberry cultivars, 'Bluecrop', 'Weymouth', and 'Tifblue', using anti-dehydrin antiserum. Proteins were extracted from the progressively dehardening buds in response to a controlled deacclimation regime (see Methods). Fifteen micrograms of protein were loaded in each lane. Molecular mass of the three dehydrins $\left(65-, 60-\right.$, and 14-kDa) is marked by arrows. DOD $=$ days of deacclimation; $\mathrm{LT}_{50}=\mathrm{a}$ measure of bud cold hardiness $(\mathrm{BCH})$. 
'Bluecrop', the slowest deacclimator. Whether the differential turnover of these dehydrins during deacclimation is directly associated with loss in cold hardiness or is a reflection of other developmental events occurring at warmer temperatures is an open question. However, our results suggest a potential involvement of the 14-kDa dehydrin in the regulation of dehardening in blueberry buds. Moreover, it is possible that certain dehydrins within the same tissues may be the targets of specific proteases that result in their preferential degradation during dehardening. Studies are underway to further characterize the 14-kDa dehydrin vis-à-vis cold tolerance of blueberry buds.

\section{Literature Cited}

Arora, R., L.J. Rowland, and G.R. Panta. 1997. Chill responsive dehydrins in blueberry: Are they associated with cold hardiness or dormancy transitions? Physiol. Plant. 101:8-16.

Arora, R., L.J. Rowland, J.S. Lehman, C.C.Lim, G.R. Panta, and N. Vorsa. 2000. Genetic analysis of freezing tolerance in blueberry (Vaccinium section Cyanococcus). Theor. Appl. Genet. 100:690-696.

Ceccardi, T.L., N.C. Meyer, and T.J. Close. 1994. Purification of a maize dehydrin. Protein expression and purification 5:266-269.

Clark, J.R., J.N. Moore, and A.D. Draper. 1996. 'Ozarkblue' southern highbush blueberry. HortScience 31:1043-1045.

Close, T.J. 1996. Dehydrins: Emergence of a biochemical role of a family of plant dehydration proteins. Physiol. Plant. 100:291-296.

Danyluk, J., A. Perron, M. Houde, A. Limin, B. Fowler, N. Benhamou, and F. Sarhan. 1998. Accumulation of an acidic dehydrin in the vicinity of the plasma membrane during cold acclimation of wheat. Plant Cell 10:623-638.

Ehlenfeldt, M.K. 1994. The genetic composition and tetrasomic inbreeding coefficients of highbush blueberry cultivars. HortScience 29:1342-1345.

Esen, A. 1978. A simple method for quantitative, semiquantitative and qualitative assay of protein. Anal. Biochem. 89:264-273.

Flinn, C.L. and E.N. Ashworth. 1994. Blueberry flower-bud hardiness is not estimated by differential thermal analysis. J. Amer. Soc. Hort. Sci. 119:295-298.

Hancock, J.F. and J.H. Sieker. 1982. Levels of inbreeding in highbush blueberry cultivars. HortScience 17:363-366.

Hummer, K., H.B. Lagerstedt, and S.K. Kim. 1986. Filbert acclimation, maximum cold hardiness, and deacclimation. J. Amer. Soc. Hort. Sci. 111:474-482.

Koag. M-C., R.D. Fenton, S. Wilkens, and T.J. Close. 2003. The binding of maize DHN1 to lipid vesicles. Gain of structure and lipid specificity. Plant Physiol. 131:309-316.

Levi, A., G.R. Panta, C.M. Parmentier, M.M. Muthalif, R. Arora, S. Shanker, and L.J. Rowland. 1999. Complementary DNA cloning, sequencing, and expression of an unusual dehydrin from blueberry floral buds. Physiol. Plant. 107:98-109.

Lim, C.C., S.L. Krebs, and R. Arora. 1998. Genetic study of freezing tolerance in Rhododendron populations: Implications for cold hardiness breeding. J. Amer. Rhododendron Soc. 52:143-148.

Lim, C.C., S.L. Krebs, and R. Arora. 1999. A 25-kDa dehydrin associated with genotype- and age-dependent leaf freezing-tolerance in Rhododendron: A genetic marker for cold hardiness? Theor. Appl. Genet. 99:912-920.

Lindstrom, O.M. and M.A. Dirr. 1989. Acclimation and low temperature tolerance of eight woody taxa. HortScience 24:818-820.

Lindstrom, O.M. and M.A. Dirr. 1991. Cold hardiness of six cultivars of Chinese elm. HortScience 26:290-292.

Manly, B.F.J. 1997. Randomization, bootstrap and Monte Carlo methods in biology. 2nd ed. Chapman \& Hall, London.

Milliken, G.A. and D.E. Johnson. 2002. Analysis of messy data-Volume III: Analysis of covariance. Chapman \& Hall/CRC, London.

Moore, J.N. 1993. The blueberry industry of North America. Acta Hort. 346:15-26.

Muthalif, M.M. and L.J. Rowland. 1994. Identification of dehydrin-like proteins responsive to chilling in floral buds of blueberry (Vaccinium, section Cyanococcus). Plant Physiol. 104:1439-1447.

Pauley, S.S. and T.O. Perry. 1954. Ecotypic variation of the photoperiodic response in Populus. J. Arnold Arboretum 35:167-189.

Pellett, H. 1998. Breeding of cold hardy woody landscape plants, p. 317-323. In: P.H. Li and T.H.H. Chen (eds.). Plant cold hardiness: Molecular biology, biochemistry, and physiology. Plenum Press, New York.

Rowland, L.J., E.L. Ogden, R. Arora, C.C. Lim, J.S. Lehman, A. Levi, and G.R. Panta. 1999. Use of blueberry to study genetic control of chilling requirement and cold hardiness in woody perennials. HortScience 34:1185-1191.

Rowland, L.J., S. Mehra, A. Dhanaraj, E.L. Ogden, and R. Arora. 2003. Identification of markers associated with cold tolerance in blueberry. Acta Hort. 625:59-69.

SAS Institute. 1999. SAS/STAT user's guide, Vers. 8. SAS Inst., Cary, N.C.

Spiers, J.M. 1978. Effect of stage of bud development on cold injury in rabbiteye blueberry. J. Amer. Soc. Hort. Sci. 103:452-455.

Stone, J.M., J.P. Palta, J.B. Bamberg, L.S. Weiss, and J.F. Harbage. 1993. Inheritance of freezing resistance in tuber-bearing Solanum species: Evidence for independent genetic control of nonacclimated freezing tolerance and cold-acclimation ability. Proc. Natl. Acad. Sci. USA 90:7869-7873.

Svensson, J., A.M. Ismail, T. Palva, and T.J. Close. 2002. Dehydrins, p. 155-171. In: K.B. Storey and J.M. Storey (eds.). Sensing, signalling, and cell adaptation. Elsevier Sci., Amsterdam, The Netherlands.

Vega, S.E., J.P. Palta, and J.B. Bamberg. 2000. Variability in the rate of cold acclimation and deacclimation among tuber-bearing Solanum (potato) species. J. Amer. Soc. Hort. Sci. 205:205-211.

Wisniewski, M, R. Webb, R. Balsamo, T.J Close, X.M. Yu, and M. Griffith. 1999. Purification, immunolocalization, cryoprotective, and antifreeze activity of PCA60: Adehydrin from peach (Prunus persica). Physiol. Plant. 105:600-660.

Wolf, T.K. and M.K. Cook. 1992. Seasonal deacclimation patterns of three grape cultivars at constant, warm temperature. Amer. J. Enol. Viticult. 43:171-179. 